\title{
Development, motivation, change - educators' opinions about groups for teachers on Facebook
}

KEYWORDS

Facebook, support, group, teacher, development

\begin{abstract}
Anna Michniuk, Development, motivation, change - educators' opinions about groups for teachers on Facebook. Kultura - Społeczeństwo - Edukacja nr 2(20) 2021, Poznań 2021, pp. 111-122, Adam Mickiewicz University Press. ISSN 2300-0422, ISSN (Online) 2719-2717. DOI 10.14746/kse.2021.20.6
\end{abstract}

The aim of the article is to describe support that can be observed in online Facebook teachers' groups created and administered by teachers or institutions connected with education. The author presented selected Facebook groups, indicated their aims and activities undertaken in their space. On the basis of the conducted research $(n=548)$, the article will also discuss teachers' motivations for joining the groups and their reflections connected with belonging to them.

\section{Introduction}

Facebook is currently the most popular social network on the Internet. According to data published on Statistica.com, the website established by Harvard students had more than 2.6 billion active accounts each month in the first quarter of 2020 (Clement, 2008). It has over 100 million users in the following countries: India (290 million), the United States (190 million), Indonesia (140 million) and Brazil

\footnotetext{
* ORCID: https://orcid.org/0000-0002-5939-1371.
} 
(130 million) (Clement, 2020). In Poland, 89\% of people between 16 and 64 years of age declared using Facebook in the month preceding the survey. Only YouTube was more popular in our country. Most of the respondents (96.2\%) used Facebook on mobile devices (Kemp, 2020). The Polish version of the portal first appeared in 2008 and quickly became popular. It had over 10 million users as early as 2011 (IAB Polska, 2019/2020).

Currently, the website offers a lot of functionalities. The basic one is the person's own Facebook page (profile) or fanpage in the case of a company or institution. On the pages you can publish photos, videos, posts, reports, and rate products and services. Events have a special format. These are special pages for events organized by individuals, group or companies. Because of these, in one place you can present the planned and implemented events, invite people to participate, and provide information related to the events. Importantly, when you are interested in a specific Event, you do not have to follow / like the organizer's profile.

On your Facebook page, you can also broadcast live video, publish stories that are available only 24 hours after posting, create short polls, publish job offers, share notes (longer entries like those we know from blogs), conduct activities related to e-commerce, as well as create groups that connect people with similar needs, problems or interests. This article deals with the subject of Facebook groups, created and conducted with teachers in mind.

\section{Facebook groups - types and characteristics}

One can distinguish two types of groups on Facebook: private and public. A group can be created by any user of the social network. In the public, open groups, everyone has access to the posted, shared and commented posts. The list of group members, administrators and moderators is available for all Facebook users. In the case of a private, closed group, the data contained in the group and information about members are available only to current members of the group. Facebook reserves the right to check the content of the group (also with the status of a private group) so that the activities undertaken by members are legal and participation in them is safe for all users (Facebook, https://www.facebook.com/help/220336891328465?h elpref=about_content, 23.07.2020).

Group administrators can choose what type of community they run. Facebook offers users six types of groups to help achieve specific goals. These are: General, Buy and Sell, Social Learning, Video Games, Work and Job Offers. The first one is default and includes a standard set of tools. The second one allows to prepare and 
publish sales offers within the group. Users can list items for sale, search for what they need, and tag items that have already been sold. When creating posts, it is required, among other things, to specify the currency in which the transaction will be made. In a group with the Social learning type, you can create quizzes, lessons (which are included in the Modules) and track the progress of group members. Another type -video game-based groups - is associated with specific games, so that you can plan and organize tournaments for group members. Work is a type of group that allows you to publish information about changes within one institution or company. Members do not have to be friends to be able to receive or exchange information. The last type - Job offers, is the type of group that includes a list of work vacancies, along with their location, proposed salary and shortened requirements (Facebook, https://www.facebook.com/help/703062606492033?helpref=uf_permalink, 08.07.2020). The group type can be changed at any time.

In the spring of 2020, Facebook launched another option related to the creation of groups - Messenger Rooms. At the same time, up to 50 people can stay in one room. Importantly, you don't need to be a Facebook user to be invited to participate in a conversation. A characteristic feature of the Rooms is that it is possible to change the background, adjust the light or insert stickers. The Room creator may remove unwanted participants at any time (Facebook, https://www.facebook.com/ help/messenger-app/819584731857901, 23.07.2020). Rooms are a good solution for people who do not want to create a group, and their purpose is to organize a virtual meeting with more people who do not necessarily use their profiles on Facebook.

\section{Support and its elements in social media}

Support means "help given to someone, especially material help", and supporting is nothing more than "leaning on something, supporting something from below or from the side" (Słownik Języka Polskiego PWN, https://sjp.pwn.pl/szukaj/wsparcie.html, 11.08.2020). The issues of support discussed in the literature on the subject are very often presented in the category of social support. This concept has been present in numerous theoretical and research works since the seventies of the twentieth century. It was associated with life stress and crisis events occurring in human life (more: Sęk, 2005: 87-107). The most general definition is that social support is "to provide an individual who experiences some kind of difficulty, emotional, information, or material resources from other people" (McDowell, Newell, 1987, za: Kacperczyk, 2006). 
Researchers dealing with the subject of support have distinguished various types of support, including instrumental, informative, emotional, evaluating and integrating (Sęk, Cieślak, 2004). It should be emphasized that these are not mutually exclusive. One behaviour can very often be classified into different types of support.

In the context of Facebook groups, an important concept is online social support defined as "help available to an individual in a critical situation, the overcoming of which requires the use of external resources from virtual groups, gathering people struggling, in the past or now, with similar difficulties. character". This kind of support is usually not professional. It is based on the experience of Internet users (Walter, 2016: 76).

Online support, just like traditionally understood social support, can be of various types, for example: informational (providing tips, advice), instrumental (specific form of informational support), material (in-kind or financial support), emotional (building a sense of security, improving self-esteem, allowing you to get closer to mental well-being) (Walter, 2016: 76-85). Each of the types of support, as shown in the research discussed below, is present to a greater or lesser extent in the teacher groups existing on the Facebook social network.

The link between the concept of support and social media, which has "social" in its name, seems quite obvious. As mentioned, support means help. But social media are defined as part of the new media related to the development of the Internet, serving to connect people into groups and communities. Through them, users interact with each other (Kietzmann, Hermkens, McCarthy, Silvestre, 2011), and thus help one another. These are local and global media that are created, published and disseminated using free tools available on the Internet and on mobile devices. Their characteristic feature is that (often) there is an immediate interaction between senders and recipients of messages.

The social media groups, despite the fact that they are virtual groups, in which there is rather no real, "analog" contact, can successfully be a source of social support. Groups active in the space of the Facebook social network bring together people with similar interests, experiences and needs.

In Facebook groups, members can share their thoughts or ideas, inspire each other, and exchange what they created. In the context of support in the space of social media, one can talk about the phenomenon of digital altruism, which was widely analysed by Natalia Walter in the book Internet social support. A socio-pedagogical study. Wikipedia, educational channels on YouTube and charity fundraising conducted, for example, by Siepomaga.pl (an online helping platform) are excellent examples of the fact that Internet users are often volunteers who have a huge impact on the digital space (Walter, 2016: 66-79). 


\section{Examples of social media groups for teachers, counsellors and educators}

The article will discuss three selected groups that function on Facebook: @ktywni - podążaj odważnie za nowoczesna edukacja, Ja, Nauczyciel and Nauczycielki przedszkola. Each of the selected groups is different, has different goals and functions in a slightly different way.

The first group, @ktywni - podążaj odważnie za nowoczesna edukacja (now July 2021 it is called $Z$ klasq), was founded in 2018 by the Polish publishing house MAC Edukacja. The aim of the group is to disseminate the information about innovations in education, both those related to technology and those based on soft skills among teachers. The group regularly hosts webinars - virtual seminars where group leaders discuss various intriguing issues. Meetings typically last around 45 minutes. The participants can ask questions to the presenters during the webinar via chat. The group's leaders include: Roman Lorens (a specialist in educational law, trainer, expert of the Ministry of National Education in the implementation of the core curriculum, long-term lecturer, former director of a general secondary school), Anna Albrecht (certified teacher of early school education, fan of creative activities, founder of the blog "Szkolne Inspiracje" and the administrator of the fan page "Kwadrans z Edukacją"), Bartosz Chyś (nominated for the title of Teacher of the Year 2019, active eTwinner, member of the "Superbelfrzy RP" group) and Anna Michniuk (enthusiast of new media, academic lecturer, media educator). Virtual meetings were also conducted by: Dawid Lasiński (chemistry teacher, known in social media as Pan Belfer) and Agnieszka Iwanicka, assistant professor at the Department of Media Education at the Adam Mickiewicz University in Poznań. The group is constantly expanding. Currently (as of 7/06/2021) it consists of over 34 thousand members. According to the group administrators, there are more webinars planned that will help the teachers gain new competences related to creative, modern and new media education.

Another example is the group Ja, Nauczyciel. In July 2020, it had 47,095 members, now (as of June 2021) it is more than 55 thousand. It was established on October 11, 2017. The description of the group stated that it was created by leaders of education in order to create a space for discussion about changes in contemporary Polish education, to support, inspire and initiate new actions. This is not just a group for teachers though. The founders are aware that cooperation is needed to bring change, so the group is open to everyone, that is, it is private, but anyone can join it (Facebook, https://www.facebook.com/groups/369251236818603/about, 08.08.2020). 
The group was created during a situation where the education reform was introduced in Poland, abolishing lower secondary schools (gimnazjum) and restoring an eight-year primary school. The belief that something should be changed in Polish education began to grow in the teachers opposing the changes. The teachers, thanks to Facebook, found a space to discuss problems, exchange opinions, and create bottom-up initiatives that were to lead the Polish school in the right direction. This group also played an important role in 2019, when teachers joined a nationwide protest action aimed at, among others, getting raises. On a daily basis, teachers - the members of the group, share various articles there, comment on them, and discuss topics raised. The group's files include a remote education guide (useful during compulsory remote learning introduced in spring 2020), inspiring teaching materials for printing, lesson plans, cooperation offers or even professional development plans. Teachers in the indicated group support each other both in substantive issues as well as those related to the performance of their duties in a more effective manner.

The last group that will be introduced is Nauczycielki przedszkola group. It was established in July 2011 and currently (as of August 9, 2020) has over 20,000 members. As we read in the description of the group, its member may be a person whose professional activity concerns children or is interested in working with children (teachers, parents, students of pre-school and early school education). In the group space, members share their ideas for activities, prepared worksheets or templates. They conduct discussions on topics important to them, advise on issues related to career advancement, and send inspirational links.

The element that connects all three groups is the initial verification - to join the groups, you need to answer the questions provided by the administrators (they mainly concern the motivation to join and the workplace or level of education at which you work). Each group has its own regulations, due to which administrators and moderators take care of the order in the published posts and to maintain correct relations between group members.

\section{Support in teacher Facebook groups in the opinion of their members}

\section{Description of the research and the study group}

The research was quantitative. The aim was to analyse the support experienced by educators - the members of various Facebook groups, the teachers' motivation to join such groups, topics that are and should be discussed in them, how the groups are used and what content they convey. 
The prepared survey questionnaire consisted of closed and semi-closed questions, questions with a scale and one open question. It was shared online in 6 teacher groups on Facebook, which have more than twenty thousand members. The survey was shared both in groups described above, as well as in others in which the approval of administrators to publish a link to the form was obtained.

The survey was available between $4^{\text {th }}$ and $10^{\text {th }}$ August 2020.548 people replied to the prepared questions. Women constituted the vast majority (97\%). The most numerous group of respondents were teachers aged 41 to 50 (41\% of all respondents). Every second respondent worked in the countryside (26\%) or in the city up to 50,000 inhabitants (26\%).

Primary school was the main workplace for $64 \%$ of respondents. Most of the respondents were certified teachers (61\%). Only 5 trainee teachers and 4 students of pedagogy took part in the survey. The main subjects taught by the respondents were preschool and early school education - $25 \%$ of the respondents, science subjects (mathematics, physics, chemistry, biology, geography) $-23 \%$ and humanities $-22 \%$.

\section{The results of the research}

Most of the respondents (35\%) belonged to more than 5 teacher groups on Facebook. Slightly less, $32 \%$ of respondents, declared that they belonged to 2-3 groups. $6 \%$ of the respondents belonged to just one group. The main reasons why the respondents joined various teaching groups were $(n=1,458)$ : 1$)$ looking for new inspirations (33\%), 2) willingness to develop their competences, for example in media or therapy $(19.4 \%), 3)$ willingness to check if other teachers face similar problems (19.3\%). Favourite groups, most often indicated by respondents, were: @ktywni - podążaj odważnie za nowoczesna edukacja (28 responses); Digitalni i kreatywni nauczyciele z pasja (25 responses), Ja, Nauczyciel (19 responses).

Almost half the respondents (48\%) visited the Facebook groups for teachers to which they belonged every day. Less than $30 \%$ did it several times a week, while $19 \%$ visited when the post appeared interesting for them. It should be noted that the respondents know who administers the groups they joined (41\%) or they know where to check who is responsible for the implementation of such activities (39\%).

Although $75 \%$ of respondents shared their experience at least once in a Facebook group for teachers, the majority $(72 \%)$ described themselves as observers who sometimes comment, like or share something. $9 \%$ of the respondents declared high activity in groups, publishing posts and participating in discussions very often. 
Posts that were most often published in groups included $(n=1,825): 1)$ proposed activities for students (already prepared worksheets or scenarios) (23\%), 2 ) webinars, live and online meetings (15\%), and 3) questions from other teachers (14\%). Posts and content containing analyses of educational law, industry articles, expert advice, training with certificates, reports from everyday life were less frequent.

When asked about what the teachers $(n=969)$ were missing in the groups to which they belong, most respondents indicated the answer "expert advice" (19\% of answers). The following positions were taken by: analyses of educational law issues (14\%), interesting industry articles (12\%) and training courses with certificates $(12 \%)$. Fewer respondents indicated already prepared lesson plans and worksheets.

In Facebook groups, the respondents are most disturbed by quarrels (30\%) and hate $(30 \%)$ that appear in discussions. $17 \%$ of respondents also mentioned advertisements published from outside the industry. In the "other" category, teachers included, among others: questionable (auto)advertising of courses, recurring issues resulting from the failure to read previous entries, political propaganda, adding people other than teachers to the group, "hysterical" requests for reports or development plans.

The respondents indicated that they use the content and knowledge gained through participation in groups several times a semester (38\% of respondents), use it constantly (25\%) or several times a month (18\%).

In the questionnaire provided, teachers were asked to rate, on a five-point scale, statements related to the support received in groups. One was the lowest (I completely disagree with this statement), 5 - the highest (I completely agree with this statement). The respondents admitted that in Facebook groups teachers are kind and willing to help others (average grade 3.84) and support each other emotionally (average 3.23). According to the respondents, groups motivate and inspire to practice the teaching profession (average mark 3.74), however, they do not necessarily help in obtaining professional promotion (average mark 2.37). The lower grade obtained may be due to the fact that the majority of the respondents (62\%) are certified teachers who have already achieved the highest level of professional promotion and did not seek information on this subject in the groups. Most of the respondents fully agreed with the statement that "Facebook groups for teachers provide ideas for tasks for students (for example worksheets, already prepared scenarios)" (average 3.87). The teachers also admitted that they receive the substantive support they need (average grade 3.38 ) and find many answers to their questions (average grade 3.57 ) in these Facebook groups. 
In reference to the questions asked, it was interesting to find out what the teachers had written in the space left for their own reflections. In the only open-ended question included in the questionnaire, the respondents had the opportunity to present their thoughts on teacher groups on Facebook. After analysing the 136 answers given, it can be noticed that teachers appreciate Facebook groups very much, because they have gained space for contact with teachers from all over the country or even the world. They are no longer limited to drawing inspiration from subject groups or methodological groups operating in the space of their locality:

- I really respect the Polish teachers who share their work. I appreciate it! Thanks to them, I create materials myself, however, for fear of criticism and misunderstanding, I do not have the courage to publish my own materials. What I create, I willingly share at work. I would not dare to criticize anyone, because I know how long it takes to prepare materials, presentations, worksheets, etc. I would also like to say that I have NEVER learned so much at any training in PCEN [teacher training centre - author's note] as much as in the Poloniści z pasja group (humanities teacher, $41-50$ years old);

- These groups provide support - they have partially filled the gap left by methodological teams operating in the regions (science teacher, 41-50 years old);

- I consider the creation of these groups and the opportunity to exchange experience with teachers from all over Poland, and not only the surrounding area to be a plus of remote learning (physical education teacher, 31-40 years old).

The thing that irritates teachers are naive entries and, according to respondents, funny questions that indicate a huge ignorance among teachers or simply a lack of professional approach to their profession:

- Naive entries and funny questions irritate me (physical education teacher, 51-60 years old);

- Unfortunately, we are largely a group that preys on the work of others, each critical voice is perceived as an attack, no one wants to admit that there are black sheep among us as well. A dozen or so enthusiasts are used by other teachers and think that by paying for the materials, they can use them as their own - by adding them to their promotion papers or pasting on their school website after minor modifications. I am annoyed by questions by for example appointed teachers - what innovation can be made for a diploma - you have no ideas; you do not know what it means that you do not deserve the title of certified teacher. This is not an internship, where you still have the right not to know many things (science teacher, 41-50 years old).

A big problem, especially in some groups, are the political overtones and discussions related to it, which introduce huge chaos and unnecessary quarrels. There is also a lot of criticism that knocks the winds out of teachers' sails: 
- I get nervous when passive users point out mistakes or make comments in an inelegant way, and they do not publish anything. Example: I experienced the fear of publishing interesting content or questions during the holidays, because some people even ridiculed them. However, the words of appreciation are very nice, it inspires me (humanities teacher, 41-50 years old);

- The groups should not get involved in politics, incite teachers, persuade them to hate, it is not in line with the teaching profession (science teacher, 41-50 years old).

In their opinions, the teachers also emphasized that in the groups they receive a lot of methodological support (which is confirmed by the results of the research), but they lack mental training and psychological consultations. They will be happy to join groups in which there would be something useful for them, to do this hard work and to simply live:

- It's good that there are such groups, they give me a lot of inspiration. They didn't help me in my promotion, because when I did it many years ago, Facebook wasn't there yet :) (humanities teacher, 51-60 years old);

- I am glad that teachers create and belong to such groups, because despite the huge amount of work we have every day, there will always be someone who shares what they have - materials, a good word, knowledge, support ... (science teacher, 31-40 years);

- Teachers are not looking for development but more for support. But a group can be a reflection space. Other things are additional: tools, inspiration ... (teacher, 41-50 years old).

\section{Findings}

The collected data showed that teachers are very eager to join the groups set up for them on the Facebook social network. Most of the respondents are members of more than one group. Teachers enter such groups mainly to find inspiration for their work and enrich their workshop.

There are many groups for teachers on Facebook. Each teacher can find something that shall interest him. Regardless of whether these interests are pre-school and early childhood education, vocational subjects, science subjects, humanities, media competences, therapeutic exercises or aspects related to professional promotion and educational law.

Support received by teachers belonging to Facebook pedagogical groups is most often related to informational, emotional and cognitive aspects. Group members are eager to share their ideas for classes, already prepared lesson plans, worksheets, and advertise their training plans and original activities. Some of the respondents are disturbed by the fact that teachers, sometimes forcefully, advertise their trainings or products (such as worksheets, decorations for kindergarten windows). According to many respondents, the goal of the Facebook group should 
be to willingly exchange, not the desire to earn money. It can therefore be noticed that, in the opinion of the respondents, in the first place there are aspects related to digital altruism - simply helping others and not caring for money.

With the topic of support in teaching groups, it could be expected that they would include rather younger teachers, with a lower degree (interns, contracted teachers), who have less experience, need inspiration or help in planning classes and move freely within the social media. However, the situation is completely different. The vast majority of the respondents are middle-aged certified teachers. As they declared, the group did not help them in their professional advancement because they could no longer achieve a higher rank. Perhaps they joined groups because, after many years of work, they were looking for something new? In order to answer this question, in-depth qualitative research should be carried out.

Teachers from the groups in which the study was conducted assessed that in the groups they did not lack methodological support, but rather: 1) mental support, with the help of which they would be able to do something for themselves; 2) legal support, which would allow you to familiarize yourself with the issues of education law; 3) expert support, which will further improve their workshop. The direction teachers want to follow is therefore related to a sense of well-being, contentment and peace, as well as confidence in what they do. This is not surprising, since the authority of the teachers is so often called into question in Poland.

\section{Conclusions}

The conducted research has clearly shown that teacher groups on Facebook bring many benefits to the teachers that joined them. Teachers can find a lot of emotional, informational, instrumental or even material support concerning the issues related to the teaching profession. The respondents indicated that they willingly exchange their original materials, inform about vacancies, and invite themselves to professional cooperation. Group members help each other in teaching situations, with a "difficult parent" and legal issues. Sometimes in Facebook groups unnecessary hate, criticism, and even offensive quarrels with a political and propaganda overtone appears. Teachers deeply regret the fact that there are people in their profession who lack personal culture. However, arguments or different roles appearing in groups are natural. The functioning of groups has its own, more than once described, characteristics (more: Brown, 2006; Heidtman, Wysieńska, 2013; Oyster 2002). Not many works have been written about the specificity of Facebook groups. This is definitely an area for further research. 
Finally, it is worth noting (that was also mentioned by the respondents) that thanks to the teacher groups operating in the Internet space, educators gained a new space to exchange ideas, views and solutions. They are no longer limited by time and place when it comes to necessary consultations or participation in interesting meetings. Facebook groups created an opportunity to cooperate with teachers from different parts of the country and even from around the world. They are a great example that new media are not only a place of entertainment or fun, but also an effective tool for establishing, building and maintaining relationships and providing mutual help in various situations.

\section{Bibliography}

Brown R. (2006), Procesy grupowe. Dynamika wewnątrzgrupowa i międzygrupowa, Sopot.

Clement J. (2008), Facebook: Number of Monthly Active Users Worldwide 2008, https://www.statista.com/ statistics/264810/number-of-monthly-active-facebook-users-worldwide, accessed: 09.08.2020.

Clement J. (2020), Countries with the Most Facebook Users 2020, https://www.statista.com/statistics/268136/top-15-countries-based-on-number-of-facebook-users, accessed: 09.08.2020.

Facebook, Czym są typy grup na Facebooku i jak mogę zmienić typ swojej grupy?, https://www.facebook.com/help/703062606492033?helpref=uf_permalink, accessed: 08.07.2020.

Facebook, Informacje o grupie Ja, Nauczyciel, https://www.facebook.com/groups/369251236818603/ about, accessed: 08.08.2020.

Facebook, Jak działa funkcja Pokoje Messengera?, https://www.facebook.com/help/messenger-app/819584731857901, accessed: 23.07.2020.

Facebook, Jakie są dostępne opcje prywatności grup na Facebooku?, https://www.facebook.com/help/ 220336891328465?helpref=about_content, accessed: 23.07.2020.

Heidtman J., Wysieńska K. (red.) (2013), Procesy grupowe. Perspektywa socjologiczna, Warszawa.

IAB Polska (2019/2020), Przewodnik po social media w Polsce, https://iab.org.pl/wp-content/uploads/2020/01/IAB-Przewodnik-po-Social-Media-w-Polsce-2019-2020.pdf, accessed: 09.08.2020.

Kacperczyk A. (2006), Wsparcie społeczne w instytucjach opieki paliatywnej i hospicyjnej, Łódź.

Kemp S. (Wearesocial.pl, Hootsuite, 2020), Digital 2020: Poland, https:/datareportal.com/reports/ digital-2020-poland, accessed: 09.08.2020.

Kietzmann J.H., Hermkens K., McCarthy I.P., Silvestre B.S. (2011), Social media? Get serious! Understanding the functional building blocks of social media, Business Horizons, 54(3), pp. 241-251, http://www.sciencedirect.com/science/article/pii/S0007681311000061, accessed: 09.08.2020.

Oyster C.K. (2002), Grupy, Poznań.

Sęk H. (2005), Rola wsparcia społecznego w sytuacji kryzysu, [w:] D. Kubacka-Jasiecka, T.M. Ostrowski (red.), Psychologiczny wymiar zdrowia, kryzysu i choroby, Kraków, pp. 87-107.

Sęk H., Cieślak R. (2004), Wsparcie społeczne, stres i zdrowie, Warszawa.

Słownik Języka Polskiego PWN, hasło „wsparcie”, https://sjp.pwn.pl/szukaj/wsparcie.html, accessed: 11.08.2020.

Walter N. (2016), Internetowe wsparcie społeczne. Studium socjopedagogiczne, Poznań. 